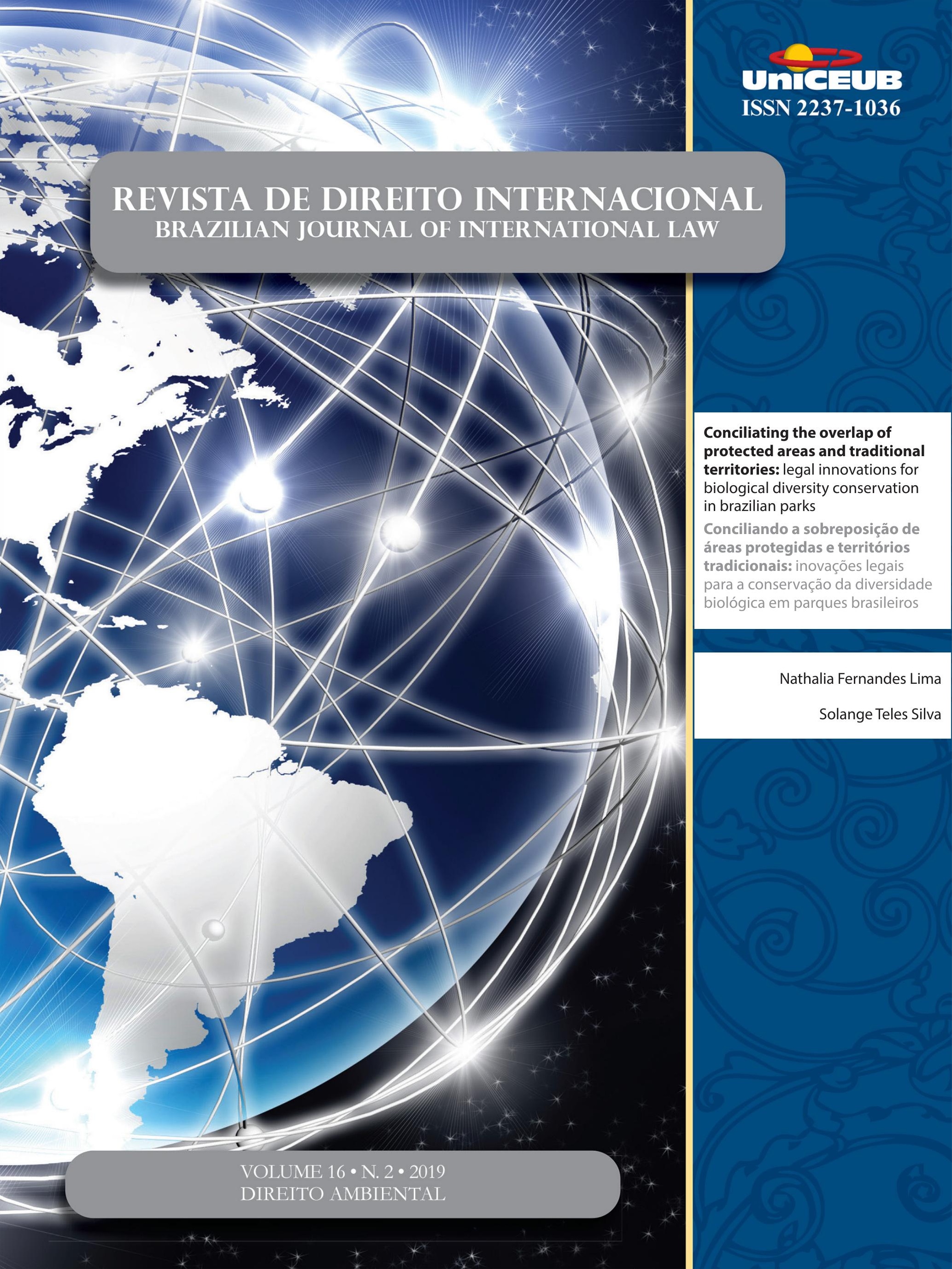




\section{Sumário}

I. Crônicas do Direito Internacional .................................................1

AMAZONIE: LE DROIT INTERNATIONAL EN VIGUEUR APPORTE DES RÉPONSES SUBSTANTIELLES ... 3 Pierre-Marie Dupuy

A eVOluÇão da SOluÇão DE CONTROVÉRSias NOS ACFIs 8 Ana Rachel Freitas da Silva

II. Dossiê Especial: Direito ambientai 14

A brief overview of Sustainable DeVelopment: HOW A DEBATEd CONCEPT With A MUCH-CONTESTED LEGAL NATURE COULD PERFORM A VALUABLE ROLE IN THE DECISION-MAKING ......16 Natali Francine Cinelli Moreira

A meta 11 de Aichi e as Áreas marinhas protegidas em grande ESCALA: proteção ambienTAL OU OPORTUNISMO POLÍTICO?

Alexandre Pereira da Silva

LITIGÂNCIA CLIMÁTICA COMO ESTRATÉGIA JURISDICIONAL AO AQUECIMENTO GLOBAL ANTROPOGÊNICO E MUDANÇAS CLIMÁTICAS

Délton Winter de Carvalho e Kelly de Souza Barbosa

AsSESSMENT AND CHALlENGES OF CARBON MARKETS

Louise Pigeolet e Arnaud Van Waeyenberge

As abordagens dos países da América Latina e Caribe sobre a mobilidade humana proVOCADA PELAS MUDANÇAS CLIMÁTICAS

Diogo Andreola Serraglio e Heline Sivini Ferreira

Implementation of Legal mechanisms of environmental protection by the South PaCIFIC REGIONAL ORGANIZATIONS 116 Joanna Siekiera 
CONCILIATING THE OVERLAP OF PROTECTED AREAS AND TRADITIONAL TERRITORIES: LEGAL INNOVATIONS FOR BIOLOGICAL DIVERSITY CONSERVATION IN BRAZILIAN PARKS

Nathalia Fernandes Lima e Solange Teles Silva

O USO DE DRONES COMO INSTRUMENTO PARA A CONSERVAÇÃo DA BIODIVERSIDADE NO BRASIL141 Larissa Suassuna Carvalho Barros e Marcia Dieguez Leuzinger

Agrotóxicos e direitos humanos no contexto global: o Brasil EM Risco de Retrocesso?

Marcelo Pretto Mosmann, Letícia Albuquerque e Isabele Bruna Barbieri

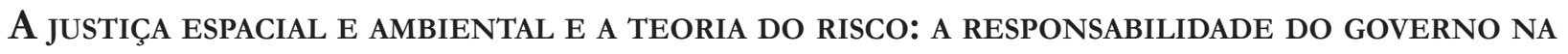
PREVENÇÃo CONTRA DESASTRES (NO BRASIL). 169

José Adércio Leite Sampaio e Edson Rodrigues de Oliveira

The judgment of the case Xucuru People v. Brazil: Inter-American Court of Human RigHTS BETWEEN CONSOLIDATION AND SETBACKS

Gabriela Cristina Braga Navarro

II. Artigos sobre outros temas

NACIONALIDADE: NOVAS REGRAS, VELHOS PROBLEMAS

226

Paulo Henrique Faria Nunes

O EXERCíCIO DA JURISDIÇÃO INTERAMERICANA DE DIREITOS HUMANOS: LEGITIMIDADE, PROBLEMAS E POSSÍVEIS SOLUÇÕES

Felipe Grizotto Ferreira, Guilherme Perez Cabrale Lucas Catib de Laurentiis

A proteção da identidade de gênero na jurisprudênCia da Corte Europeia de Direitos Humanos

Gabriel Coutinho Galil

O COMITÊ JURÍdico INTERAMERICANO dA OEA E A CODIFICAÇÃo DO DIREITO INTERNACIONAL REGIONAL. 
O caso Petruhhin e o princípio do nível mais elevado de proteção no tocante aos diREITOS FUNDAMENTAIS NO ÂMBITO DA UNIÃo EUROPEIA............................................304

Clovis Demarchi e Jaine Cristina Suzin

A AUTONOMia da VONTADE NA ESCOLHA dA LEI APLICÁVEl AOS CONTRATOS DE COMÉRCiO INTER-

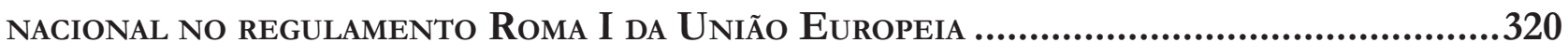

Aline Beltrame de Moura e Rafaela Hörmann

A JuRisdição da ICANN: desafios atuais e Prospectivas futuras...............................335 Aziz Tuffi Saliba e Amael Notini Moreira Bahia

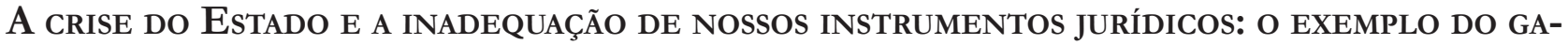
RANTISMO PENAL NO BRASIL.

Oswaldo Poll Costa e Francisco Quintanilha Veras Neto

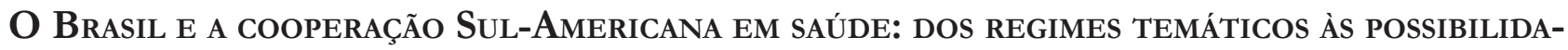
DES DE EFETIVAÇÃo ESTRUTURANTE

Ademar Pozzatti Junior e Luiza Witzel Farias

III. RESENHAS

Resenha da obra: SILVA, Waldimeiry Correa da. Regime internacional de enfrentaMENTO AO TRÁFICO DE PESSOAS: AVANÇOS E DESAFIOS PARA A PROTEÇÃo DOS DIREITOS HUMANOS. Rio de Janeiro: Lumen Juris, 2018. 385

Mércia Cardoso de Souza e Guirino Nhatave 


\title{
Conciliating the overlap of protected areas and traditional territories: legal innovations for biological diversity conservation in brazilian parks*
}

\author{
Conciliando a sobreposição de áreas \\ protegidas e territórios tradicionais: \\ inovações legais para a conservação da \\ diversidade biológica em parques brasileiros
}

\author{
Nathalia Fernandes Lima** \\ Solange Teles Silva***
}

* Recebido em 01/07/2019

Aprovado em 21/10/2019

** Mestre em Direito Político e Econômico; Assessora Jurídica na Secretaria Verde e do Meio Ambiente do Município de SP e professora de Direito Ambiental e de Metodologia de pesquisa no Centro universitário Brazcubas Educação. E-mail : Nathalia.f.lima1@gmail. com.

*** Professora do Programa da Graduação (Desenvolvimento e Sustentabilidade) e do Pós-Graduação Strito Sensu em Direito Político e Econômico da Universidade Presbiteriana Mackenzie (UPM), Pesquisadora do CNPq (2007-2010) (2012-...),. Coordenadora do Comitê de Ética em Pesquisa em Humanos da Universidade Presbiteriana Mackenzie (CEP/UPM) (2016-2019). Diploma de Estudos Aprofundados (D.E.A.) em Direito Ambiental pela Universidade Paris I (Panthéon-Sorbonne) (1994/1995), especialização na Rhodes Academy of Oceans Law and Police - Rhodes Academy (1998), Doutorado em direito pela Universidade Paris I (Panthéon-Sorbonne) (2001) e Pós-doutorado pela Universidade Paris I (Panthéon-Sorbonne) (2005). E-mail : solange.teles@terra.com.br.

\section{Abstract}

The National System of Conservation Units was introduced as part of the normative framework that regulates the creation of protected areas implemented by the Convention of Biodiversity. Here we analyze particularly protected areas, specifically those that do not allow the direct use of natural resources and predict that the traditional populations residing within its boundaries should be relocated. However, until you can perform this resettlement, the government may take action in order to reconcile the permanence of these populations for the purposes of the unit. Our goal was to identify and analyze the legal innovation adopted by the management bodies of Brazilian Parks of State and Federal in order to ensure the right's of traditional population living in these areas. First, we conducted an exploratory study using the Citizen Information System to raise the cases of overlapping full protection conservation units to traditional lands and territories. After this step, we conducted a cutout in the research object to analyze only the Park category and we chose the empirical research methodology with application of documentary research method in the field of official public documents, namely, the management plans of federal parks and state approved and available on the website of the Chico Mendes Institute for Biodiversity Conservation and state Departments of the Environment of all federal entities. We note that other solutions are adopted and not included resettlement as the first solution in all cases. In reality, there are several compositions using different legal instruments.

Keywords: Protected areas. Cultural heritage. Intangible assets. Lands and Traditional 


\section{Resumo}

Objetivo do artigo foi mapear e analisar as soluções adotadas pelos órgãos gestores das unidades de conservação de proteção integral, estaduais e federais, sobrepostas aos territórios tradicionais. Primeiro, realizamos uma pesquisa exploratória com a utilização do Sistema de Informação ao Cidadão para levantar os casos de sobreposição das unidades de conservação de proteção integral às terras e territórios tradicionais. Após essa etapa, realizamos um recorte no objeto de pesquisa para analisarmos a categoria Parque e optamos pela metodologia de pesquisa empírica, com aplicação do método de pesquisa documental no campo de documentos públicos oficiais, quais sejam, os planos de manejo dos parques federais e estaduais aprovados e disponibilizados no site do Instituto Chico Mendes de Conservação da Biodiversidade e das Secretarias estaduais do Meio Ambiente de todos os entes federativos. Constatamos que outras soluções são adotadas e o reassentamento não figura como a primeira solução em todos os casos. Em realidade, há composições diversas que utilizam diferentes instrumentos jurídicos. Além disso, essa diversidade de soluções foi identificada quando analisamos separadamente aquelas adotadas nos casos de sobreposições de parques às terras indígenas, quilombolas e comunidades tradicionais, o que pode indicar a influência do regime jurídico de reconhecimento dos direitos territoriais que se difere para cada um desses povos e comunidades. Por fim, constatamos ainda a existência de soluções diversas em cada uma dessas esferas da federação, o que pode representar o respeito à autonomia politico-administrativa, bem como a complexidade de cada caso envolvendo múltiplas dimensões, desde as características socioculturais e espaciais até as questões econômicas em cada região.

Palavras-chave: Áreas Protegidas; Patrimônio Cultural; Patrimônio Natural; Sobreposição e Territórios Tradicionais.

\section{Introduction}

The Convention on Biological Diversity (CBD), an internationally legally binding treaty, that covers biodiversity at tree levels - ecosystems, species and genetic resources - has three main goals: conservation of biodiversity; sustainable use of biodiversity; fair and equi- table sharing of the benefits arising from the use of genetic resources. This convention determine that each Contracting Party shall establish a system of protected areas to conserve biodiversity (Article 8, a ). As a strategy for biodiversity conservation, the CBD recognized the importance to preserve, respect and apply the traditional knowledge associated with the sustainable use of natural resources in the system of protected areas (Articles 8, $\mathrm{j}$ and 10, c). This perspective adopted by the Convention aims to promote the right to an ecologically balanced environment through respect of indigenous peoples and other traditional communities' rights.

Brazil has ratified this convention and in order to achieve these commitments has adopted the National System of Conservation Units (Federal Law No. 9,985 / 00), a system of protected areas - conservation units - to regulate the way that the government create and manage them. This Federal Law establishes two management categories: the full protection conservation units ${ }^{1}$, only admitting the indirect use of its natural attributes and, sustainable use conservation units ${ }^{2}$, which allow environmental exploitation, but in a manner that ensures the preservation of the environmental resources and biodiversity in a socially just and economically viable way.

Although full protection conservation units not allow the direct use of natural resources, various units of this category, such as national and state parks ${ }^{3}$ have been created overlapping ${ }^{4}$ the lands and territories ${ }^{5}$ ocArt. 8 - The group of Integral Protection Units consists of the
following categories of protected areas: I - Ecological Station; II
- Biological Reserve; III - National Park; IV - Natural Monument;
V - Wildlife Refuge
2 Art. 14 - They are the Group of Sustainable Use Units the fol-
lowing categories of protected areas: I - Environmental Protection
Area; II - Area of Relevant Ecological Interest; III - National For-
est; IV - Extractive Reserve; V - Wildlife Reserve; VI - Sustainable
Development Reserve; and VII - Private Natural Heritage Reserve.
3 In topic 2 we will present the collected data.
4 LEUZINGER, Márcia Dieguez et al. Espaços territoriais es-
pecialmente protegidos: extensão, limites e oportunidades. Bra-
sília: Uniceub, 2015. LEUZINGER, Márcia Dieguez; LINGARD,
K. The Land Rights of Indigenous and Traditional Peoples in Bra-
zil and Australia. Revista de Direito Internacional, v.13, p.60-80,
2016. LEUZINGER, Márcia Dieguez Natureza e cultura: uni-
dades de conservação de proteção integral e populações tradicionais
residentes. Curitiba: Letra da Lei, 2009.
The traditional lands and territories terms are considered in this
work as necessary space for the cultural, social and economic repro-
duction of traditional people and communities, whether used per-
manently or temporarily, noted, with regard to indigenous peoples
and quilombolas respectively, available in the Articles 231 of the Con-
stitution of 1988, also 68 of the Constitutional Provisions Decree 
cupied by indigenous people ${ }^{6}$, quilombolas ${ }^{7}$ and others traditional communities ${ }^{8}$.

Studies have been made analyzing this overlap focus on social and environmental conflicts considering the expropriation of community's land and case studies. Nevertheless, we do not found studies considering a quantitative analyze mapping the legal solutions that have been brought to this kind of overlapping. In one hand, the Law No. 9,985/00 establishes that traditional populations living in protected areas which does not allowed people residing inside its border shall be relocated and compensated by the government (Article

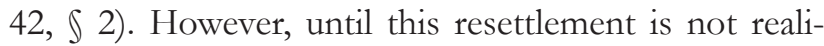
zed, specific rules and actions must be adopted to reconciliate the presence of traditional populations ${ }^{9}$ with the unit's objectives, without prejudice to their ways of life, sources of subsistence and their dwelling places. A temporary alternative, till the resettlement is carried out, has been established by Decree No. 4.340 / 02 (which

No. 6,040 / 07, Article 3-II).

6 Article 1 of the Convention 169 of the International Labor Organization (incorporated by Decree No. 5,150 / 04) distinguished indigenous people of other communities termed as tribal because of their descent from the populations which inhabited the country at the time of conquest or colonization.

Quilombola communities were defined by the Brazil Quilombola Program of the National Secretariat for the Promotion of Racial Equality of the Ministry of Human Rights as "groups with their own historical trajectory, whose origin refers to different situations, like land donations from the breakdown monocultures; purchase of land by the individuals themselves, with the end of the slave system; land obtained in exchange for the provision of services; or occupied areas in the resistance process to the slave system ". The Brazil Quilombola Program also recognizes that, in all cases, the territory is the basis of physical reproduction, social, economic and cultural life of the community these groups

8 Article 1 of C169OIT set tribal people to which the Convention applies to those who's social, cultural and economic conditions distinguish them from other sectors of the national community, and whose status is regulated wholly or partially by their own customs or traditions or by special legislation. Decree No. 6,040 / 07 has defined traditional communities as culturally distinct groups and is recognized as such.

9 The term from traditional populations was used by the National Protected Areas System (Federal Law 9.985/00) (Law No. 9.985 / 00). Although, theoretically, the indigenous people they should not be included in this term, the fact that the Federal Law 9.985/00 established the relocation of traditional populations from their territory in cases they are overlapped on full protection units, the 1988 Constitution recognized for the indigenous the original right over their lands and banned their removal. However, in practice, there are fully protected conservation units overlapped on indigenous lands. Therefore, in this study, the term traditional populations will be used as a synonym for indigenous people, quilombolas and other categories of traditional communities regulated the Federal Law 9.985/00): the celebration of Commitment Agreements (CA). In other hand, governing body of the conservation units of integral protection had also adopted others solutions, stablishing for example zones of cultural protection.

Given this conflict between nature and culture ${ }^{10}$, generated by the incompatibility between the norm and reality in fact, the main objective of this work is to identify the legal solution(s) adopted by the governing body of the conservation units of integral protection, considering the overlap of these areas and the lands or territories occupied by traditional communities - indigenous or non-indigenous one's. We can will analyze these legal solution(s) as innovative tools in order to implement the objectives of CDB.

In order to raise data on the actions taken by the management bodies full protection conservation units we will take into account Brazilian Parks both at federal and state level (26 states members and the Federal District). First we had proceed to an exploratory study ${ }^{11}$ using the electronic system the Information Citizen Services (e-SIC) at the federal and state levels, established by the Access to Information Act (LAI). This desk research aimed to make a first step of our diagnosis and highlight possible solutions in case of conflicts, to further investigate the actions taken by the management bodies of Brazilian parks overlapping the lands and territories ${ }^{12}$

10 LEUZINGER, Márcia Dieguez Natureza e cultura: unidades de conservação de proteção integral e populações tradicionais residentes. Curitiba: Letra da Lei, 2009.

11 REGINATO, Andréa Depieri de. Uma introdução à pesquisa documental. In: MACHADO, Maíra Rocha (org.). Pesquisar empiricamente o Direito. São Paulo: Rede de Estudos Empíricos em Direito, 2017.

12 The natives was constitutionally recognized the original right of ownership of the lands they traditionally occupy, with the definition of the demarcation procedure to ensure that right. For the Quilombolas, the 1988 Constitution recognized the right of ultimate ownership by the collective title to the land of the remnants of the quilombos. But with respect to other categories of traditional communities, there is still no defined legal framework to ensure the right to their territories, although this right has been recognized by the Convention 169 of the International Labor Organization (C169OIT)and the National Policy for the Sustainable Development of Traditional People and Communities (Decree No. 6,040 / 07). In addition, the 1988 Constitution established (Article 215, \1) that the State has a duty to protect the expressions of popular cultures, not only indigenous and African-Brazilian, but also of other groups participating in the national civilization process and integrated to tangible and intangible assets, which constitute the Brazilian cultural heritage, forms of expression and ways of creating, making and living of the various groups that form Brazilian society (Article 216-I and II). 
traditionally occupied by indigenous peoples, quilombolas and / or communities traditional, to reconcile the presence of local residents with the unit's creation goals. Completing our study, we had analyzed management plans of federal and state parks where these overlapping exists, trying to highlight if there is an alignment between the strategies adopted by ICMBio (federal level) and the secretariats state of the Environment (states' level) regarding actions aimed at reconciling the permanence of the traditional populations residing with the unit's goals to achieve CDB objectives.

In the first part of this study we will analyse some theoretical aspects of the relationship between nature and culture, highliting traditional communits' rights.. In the second part we will study the solutions that we could identify in this quantitative study, trying to stress the legal innovations.

\section{Nature and culture}

The 1988 Constitution recognizes, in one hand environmental protection (art. 225) and in other hand, the protection of intangible cultural heritage (art. 215 and 216). To understand how a systematic view of both protections must be seen in an integrative way it's necessary to overcome certain obstacles. We can affirms that part of these obstacles emerges from the very embodiment of a model adoped by the infra-constitutional legislation that guided the preservation of natural resources narrowly. This transplanted model of the United States to Brazil was aimed at the preservation of natural resources and considers incompatible use of protected areas by traditional communities or populations. It assumes that the management of natural resources made in the traditional way is incompatible with the preservation strategies of nature. With its implementation, the State can run the risk of contributing to the loss of a huge intangible cultural heritage, which Diegues ${ }^{13}$ calls ethnoknowledge and ethnoscience, which are endowed with ingenious systems of natural resource management and cultural diversity. In this context, are there alternatives?

13 DIEGUES, Antonio Carlos. Sustainable Development and People's Participation in Wetland Ecosystem Conservation in Brazil: Two Comparative Studies. In: GHAI, D.; VIVIAM, J. (ed.). Grassroots Environmental Action. New York and London: Routledge, 1992. DIEGUES, Antonio Carlos. O mito moderno da natureza intocada. São Paulo: HUCITEC, 1996.
If so, these alternatives have been implemented by the actions of environmental agencies in Brazil?

\subsection{Indigenous people and traditional communities, territorial rights'}

First of all, it is necessary to distinguish between indigenous people and traditional communities. The 169 Convention of the International Labor Organization (169C OIT) $)^{14}$ brings a similar definition to the one adopted by the National Policy for the Sustainable Development of Traditional Peoples and Communities (Decree No. 6,040 / 07) dealing with the tribal people, but it makes a distinction between indigenous and tribal people. This Convention recognizes tribal people as those whose social, cultural and economic conditions distinguish them from other sectors of the national community, and whose status is regulated wholly or partially by their own customs or traditions or by special legislation (169C OIT). In addition to the recognition of tribal people, 169C OIT brings a special definition of indigenous peoples because of their descent populations which inhabited the country at the time of colonization and still retain their own social, economic, cultural, political, or part of them (C169OIT, Article 1, 1b). Even if C169OIT makes this distinction, it recognizes tribal peoples the same rights that recognizes indigenous and brings a common point to both: the importance of awareness of indigenous or tribal identity. This awareness should be considered as a fundamental criterion for determining the groups to which the provisions of this Convention (169C OIT, Article 1, 2c). The self-recognition element is also emphasized by the National Development Policy of Traditional Peoples and Communities.

Although the concepts of traditional people and communities are similar, the 1988 Constitution establishes a legal framework only for indigenous people and quilombola communities. To Indigenous people, the Constitution recognized the rights to the lands they traditionally occupy, being forbidden its removal ${ }^{15}$. In order to guarantee this right, it determines that the lands traditionally occupied by Indians are intended for their permanent possession and they shall have the exclusive use of soil resources, the rivers and the lakes existing

\footnotetext{
14 Promulgated by Decree No. 5051, 2004.

15 AMEND, S. Espacios sin habitantes?: Parques nacionales en América del Sur. Barcelona, IUCN: Ed. Nueva Sociedad, 1992.
} 
therein (CF / 88, article 231, \2). The recognition of these lands will be done by the demarcation process. The legal framework for recognition and territorial guarantee granted to Quilombola communities over their lands is a little different because in this case, the Constitution establishes the right to definitive property guaranteed by the issue of collective titles by the titration procedure (CF / 88, article 68 of ADCT and Decree No. 4,887 / 03). ${ }^{16}$

Currently, to recognize the right of ownership to the territory occupied by traditional communities ${ }^{17}$ that do not fall under the category indigenous or Quilombola, the Department of Heritage Union (SPU) has used a so-called Agreement of Sustainable Use Instrument (TAUS) ${ }^{18}$ regulated by Decree No. 89/10 of the SPU ${ }^{19}$. This legal instrument grants the right of lands' possession to traditional communities, while the right of property remains to the Union where these communities occupy areas that belong to it. ${ }^{20}$ After these initial reflections on

16 Regarding the constitutionally guaranteed land to the remnants of quilombos, in accordance with Article 68 of the ADCT, the identification procedure, recognition, delimitation, demarcation and titling was regulated by Decree No. 4.887 / 03, suffered direct action of unconstitutionality (ADI) No 3239. The lawsuit was filed by the Partido da Frente Liberal (PFL), current Democratas (DEM). Several unconstitutionalities were identified, among them the self award criteria fixed in the decree to identify the remnants of quilombos and characterization of the lands to be recognized for these communities. Overall, by majority vote, the Supreme Court declared the validity of Decree No. 4,887 / 03, thereby locking the titling of lands occupied by remnants of quilombolas communities.

17 CAPUCCI, Maria Rezende. "Aspectos fundiários das comunidades caiçaras". In: STANICH NETO, Paulo et al. (org.). Direito das comunidades tradicionais caiçaras. São Paulo: Café Com Lei, 2016. DIEGUES, Antonio Carlos. Sustainable Development and People's Participation in Wetland Ecosystem Conservation in Brazil: Two Comparative Studies. In: GHAI, D.; VIVIAM, J. (ed.). Grassroots Environmental Action. New York; London: Routledge, 1992.

18 Caiçaras communities from Ilhabela had their territory recognized by TAUS. http://litoralsustentavel.org.br/boas-praticas/ comunidades-caicaras-tem-reconhecimento-de-seu-territorio/. Accessed on 28 March 2018.

19 GRABNER, Maria Luiza. Os caiçaras e as unidades de conservação de proteção integral: convergência entre os direitos fundamentais das comunidades tradicionais e a conservação ambiental. In: STANICH NETO, Paulo et al. (org.). Direito das comunidades tradicionais caiçaras. São Paulo: Café Com Lei, 2016.

20 Through the system e-SIC (Electronic Service Information to Citizen) established by the Access to Information Act (Law No. 12,527 / 11) on 17 November 2017 we requested (Protocol 03950.003519 / 2017-55) from the Heritage Department Union some information about the TAUS, such as, a) how many TAUS have already been signed with traditional communities in living full protection conservation units ?; b) Among the signed TAUS, how many have been renovated ?;e c) It is possible to access the content? the relationship of indigenous people, Quilombola and traditional communities with their territorial rights, we can inquire about how these rights are respected or not in face of the management system of protected areas.

\subsection{Protected areas}

The CDB establishes the following definition of protected area: ${ }^{21}$ "Geographically defined area that is intended, or regulated and managed to achieve specific conservation goals." Adopting a definition very close to this, the World Commission on Protected Areas of the International Union for Conservation of Nature $(\mathrm{IUCN})^{22}$ considers protected area as an "area of land or sea as defined specifically for the protection and maintenance of biological diversity and of natural and associated cultural resources, and managed ${ }^{23}$ through legal or other to be effective. ${ }^{24}$ The definition adopted by the IUCN included the idea that protected areas should cover not only natural resources, but also the associated cultural, revealing the understanding that, as important as biological diversity is the cultural diversity associated

The response of the SPU was as follows: "Pursuant to your request, we inform you that referring to the consolidated spreadsheet TAUS, there is no such consolidated information. Contained in this context information such as the address and geodetic location, which means, at first no information on whether the community is or is not inserted in a protected area. Given this fact, a spatial query was performed on 16 records of collective TAUS we have in our database (updated at the end of 2016) and were observed no spatial overlap of collective terms with strictly protected areas in conservation units. Therefore, it is not included in our database any collective TAUS given to traditional communities inserted in protected areas. In relation to the renewal of TAUS, there is no such predictability in SPU concierge paragraph $89 / 10$, neither for ordinances preceding (repealed). Thus, there is no provision of the validity or expiration of TAUS, however, It is important to note that the terms may be canceled at any time before the prerogatives provided for in Article 12 of the SPU Ordinance No. 89/10. It also points out that the TAUS are transferable only by succession, being forbidden to transfer to third parties ".

${ }^{21}$ As explained in the introduction of this paper, when we refer to protected areas we are considering ETEPs species defined by PNAP, especially the full protection conservation units under management category established by the National Protected Areas System (federal law No. $9.985 / 00$ ).

22 In English, International Union for Conservation of Nature (IUCN).

23 WORBOys, G. L. et al (eds.) Protected Area Governance and Management. Camberra, Austrália: ANU Press, 2015.

24 According to the definition proposed by the IUCN "protected areas are lands and seas where people and communities of Earth have Recognized the special natural, biodiversity, ecological, ecosystem service and / or social and cultural values and where They have taken steps to protect These values for the long term". 
with it. This concept has not been fully incorporated by the Brazilian domestic legal system, as discussed below.

The Constitution of 1988 recognized that "everyone has the right to an ecologically balanced environment and of common use and essential to a healthy quality of life" (Article 225, caput). In order to ensure the effectiveness of this right, the government must "define, in all units of the Federation, territorial spaces and their components to be specially protected" (ETEP) ${ }^{25}$. Moreover, the 1988 constitution (Article 225, Section III) determined that any modification and deletion of these spaces will be allowed only by law. The ETEPs are areas that must observe certain restrictions established in order to ensure the maintenance of natural resources and biodiversity and ecosystem conservation. ${ }^{26}$ These spaces can only be set by the government.

The Federal Law No. 9.985 / 00 brings environmental and biocultural perspective on its text, establishing between objectives and guidelines, not only the maintenance of biological diversity, natural landscapes and water resources, but also the protection of natural resources necessary for the survival of traditional people, respecting and valuing their knowledge and culture and promoting them socially and economically. In this sense, Juliana Santilli ${ }^{27}$ explains that

\footnotetext{
“among the objectives of Federal Law 9.985/00 are not only the conservation of biodiversity, but also the conservation of social diversity within a context that favors the interaction of man with nature, and the interfaces between biological and cultural diversity."
}

Among the objectives set by this system, we have the respect and appreciation of traditional knowledge and culture. Thus, we can find guidelines to protect the intangible cultural heritage. However, the Federal Law 9.985/00 establishes two management categories of conservation units (protected areas): full protection conservation units ${ }^{28}$ and sustainable use conservation

\footnotetext{
25 It is worth mentioning that the Forest Code (Law No. 12,651 / 12) regulates other categories of ETEPs, such as the Legal Reserve (RL) and Permanent Preservation Areas (APP).

26 According to Article 2 of the Convention on Biological Diversity, ecosystem means a dynamic complex of plant, animal and microorganisms and their non-living environment interacting as a functional unit. 27 SANTILLI, Juliana. Socioambientalismo e novos direitos. Realização: Instituto Internacional de Educação do Brasil (IEB) e Instituto Socioambiental (ISA). São Paulo: Peirópolis, 2005.

28 Federal Law 9.985/00 Article 8: I - Ecological Station; II - Biological Reserve; III - National Park; IV - Natural Monument; V Wildlife Refuge.
}

units. $^{29}$

Although it includes some categories of sustainable use intended to traditional communities, such as the extractive reserve, the Federal Law 9.985/00 (Article 42) tends to disregard the contribution of traditional populations for conservation of biological diversity and the possibility of involving them in such goal, and considers its traditional activities and land use practices such as loss factors and decline in biodiversity ${ }^{30}$, in that way it provides that traditional populations living into the borders of protected areas is not allowed and they should be reallocated by the government.

The same system that allows for sustainable exploitation of natural resources believes that to ensure the maintenance of ecosystems, it's necessary to separate the changes caused by human interference. Therefore, it determines that the full protection units shall only accept the indirect use of its natural attributes, that is, one that does not involve consumption, collection, damage or destruction of resources (Federal Law 9.985/00, Article 2-VI, IX) .

In 2002, Article 39 of Decree No. 4340 regulated the resettlement of traditional populations residing in full protection conservation units and brought a legal instrument called Commitment Agreement (CA), in order to compose the conditions of stay of these populations. Although this presidential decree has submitted the terms of engagement as a temporary solution in cases of overlapping full protection conservation unit lands and traditional territories, the 1988 Constitution establishes that both environmental protection and the protection of cultural heritage are common competence of the Union, states, Federal District, and municipalities (CF / 88, article 23, III, V and VI). Therefore, other solutions could arise from the actions of environmental agencies in federal, states or municipal levels. In this study we will highlight actions that could arise from federal or state levels preparing the management plan documents of state and federal units, and adopting innovative legal solutions to reconcile the permanence of people and traditional communities with the objectives

\footnotetext{
29 Federal Law 9.985/00, Article 14: I - Environmental Protection Area; II - Area of Relevant Ecological Interest; III National Forest; IV - Extractive Reserve; V - Wildlife Reserve; VI - Sustainable Development Reserve; VII - Private Natural Heritage Reserve.

30 LITTLE, Paul E. Territórios Sociais e Povos Tradicionais no Brasil: por uma antropologia da territorialidade. Série Antropologia. Brasília: Universidade de Brasília, 2002.
} 
of protected areas; thus, maintaining both of cultural heritage material and immaterial as the natural heritage.

\section{Brazilian Parks and traditional communities}

On the context of the existence of management categories that do not recognize the presence of resident traditional populations, such as parks, overlapped on traditional lands and territories, we seek to understand what has been the alternative adopted by the management bodies of protected areas.

\subsection{The first phase of our empirical research}

\subsubsection{Almost no traditional communities living in full protection conservation units, no con- flicts...}

The first step of our empirical research, carried out according to the standards of research ethics in humans $^{31}$ trailed the following steps: we send questions forwarded to federal agency (Chico Mendes Institute for Biodiversity Conservation - ICMBio) and 26 state environmental agencies responsible for the management of protected areas and the Federal District agency. The questions proposed were: (a) which are the integral protection conservation units that have indigenous and / or traditional communities living into their borders? How many of these indigenous or/ traditional communities have been resettling? How many of these indigenous or / traditional communities signed the Commitment Agreements? ${ }^{32}$ The proceedings were conducted by means of the Law of access to Information (Law No. 12,527 / 11), through the portal of e-SIC (Service of Information Access to the Citizens) both federal and state levels. Nevertheless, the information received via e-SIC, both of state and federal level, were not sufficient to achieve the quantitative analysis of the most used tools.

\footnotetext{
31 Approval from the Scientific Technical Committee of the Foundation Forestry Department of Environment from the State of São Paulo. Letter of approval 41/18, Decree 121/17 PH.

32 The results of this research will be presented in topic 2 of this work.
}

Data obtained between November 2017 and January 2018 through the Access to Information Act give to us the following diagnostic: among 28 inquiries, we had only 13 answers and among 13 entities (ICMBio and Environmental State Agencies) only 7 assumed that they had this overlap of full protected conservation unities and traditional communities living there.

Regarding the response sent by ICMBio (via LAI), we were informed that "there are no records of traditional communities in federal conservation units typified as full protection, since these units have the basic objective of preserving nature, ridding it, as much as possible, human interference "(LAI Protocol 02680.002096 / 2017-11). This response corresponds to questions about the celebration of Commitment Agreements, but with respect to the information requested regarding the resettlement, the response was very similar. According to ICMCBio, "there are no records of traditional communities in federal conservation units typified as full protection" (LAI Protocol 02680.002097 / 2017-65). ${ }^{33}$

\subsection{Few innovative legal solutions: commitment agreement and Historical-Cultural Anthropological Zone (ZHCA).}

In April 2018, it was released by ICMBio the celebration of the Declaration of Commitment Agreement ${ }^{34}$ with the indigenous people of Pataxó ethnicity, residing in $20 \%$ of the area of the National Park of Discovery, full protection unit created in 1999 in the Atlantic Forest region, located in the coastal zone $\mathrm{e}^{35}$ of the State of Bahia at the Northeast part of Brazil. According to ICMBio, the celebration of this agreement shows a new direction in the institute's relationship with indigenous people, since the agreement may be a viable solution for other cases of overlap between protected areas and indigenous lands (ICMBio, 2018).

The main rules of the agreement were established by ethno-zoning ${ }^{36}$ the park area of overlap with the

33 E-SIC / Protocol 02680002096201711. Available in: https://esic.cgu.gov.br/sistema/Pedido/DetalhePedido. aspx?id $=$ mn8Z6n9sBxE $=$ Access: 12 December 2017.

${ }_{34}$ Chico Mendes Institute for Biodiversity Conservation (ICM$\mathrm{BIO})$, and ICMBio Pataxós celebrate a Commitment Agreement, 2018

35 MINISTRY OF ENVIRONMENT, Bahia - Coastal Municipalities.

36 Article 2 Decree No. 7.747 / 12 - Sole paragraph: They are tools for territorial and environmental management of indigenous lands, 
lands traditionally occupied by the Pataxó people. The ethno-zoning is an instrument that was set up by the National Policy for Territorial and Environmental Management of Indigenous Lands (PNGATI) through Decree No. 7747 of June 5, 2012. From the ethno-zoning, the intensive use zones were established (where there are the villas, traditional community structures as "farinheiras", fields and areas of small livestock), zones of intermediate use (where planting in agroforestry models is possible and sustainable use of small amounts of green wood) and restricted zone, which corresponds to more than $90 \%$ of the overlapping area, where only small extraction, ritualistic and tourist uses are possible (ICMBio, 2018).

With respect to the information received from the departments of Environment, from the same questions explained above, we observed that in most cases the state environmental agencies responsible for the management of protected areas celebrated agreements with the traditional resident populations. Furthermore, the relocation has been indicated as a solution in a minority of cases. Considering the number of protected conservation units that have traditional populations resident, the following solutions has been adopted by states environmental agencies: 1 case of resettlement, 3 cases of agreements commitments, , 3 cases without solution. Exploring these data, we can see that in only one case occurred resettlement, namely at the Rio Negro South State Park. Concerning the tree commitment agreements, two of them take place in Chandless State Park (Acre) and State Park Itaunas (Espírito Santo). The third one is in phase of implementation, in Bahia State: the Institute for the Environment and Water Resources (INEMA) reported that this agreement will be concluded between the residents of the state conservation units when running the Territorial Consolidation Plan. We can also report an innovative solution in the State Park of Serra do Mar (PESM), located on the coast of São Paulo State, which drew up a Plan of Traditional Use (PUT). By incorporating this document in the Park Management Plan, it has recognized the territory of traditional community, thereby ensuring the sources of

also the ethnomapping and ethno-zoning. For purposes of this decree, are considered: I - Ethnomapping: participatory mapping of the areas of environmental relevance, socio-cultural and productive for indigenous people, based on indigenous knowledge; II - Ethnozoning: participatory planning instrument aiming for the categorization of areas of environmental relevance, socio-cultural and productive for indigenous people, developed from ethnomapping livelihood of traditional populations residing in Pincinguaba Center through the establishment of the Historical-Cultural Anthropological Zone (ZHCA).

\subsection{The second phase of our empirical research}

\subsubsection{Parks and traditional population}

Out of the 28 referrals sent (states, Federal District and Union), only 13 were answered. In these, we check to the unit's management plan, found some conflicting information ${ }^{37}$ in the response received, both at the federal and in the state level. From that diagnosis did a cutout in the research object with respect to the kind of unity of management category. We chose to pursue in the management plans (public documents) are more parks (kind of drive conservation of integral protection), state or federal, have adopted innovative alternatives (for example, the ZHCA PESM) in cases of overlap the traditional lands and territories. This research aimed to evaluate, especially if the zoning established by the management plan was used as a conciliator instrument and protector not only of natural resources but also the intangible cultural heritage.

This second stage of the research aimed to first identify which federal and state parks have approved management plans, and in a second stage, to locate in the document itself, which units are overlapped on indigenous lands and / or quilombolas and / or occupied territories by traditional communities. From the overlapping situations encountered, we verified that the management plans proposed some solution. The methodology used for this step was empirical, with the documentary research method in the field of official public documents, namely, the management plans (of all Brazilian parks) approved and available in ICMBio the site and state environmental agencies responsible for management of protected areas.

First, we performed a search on the websites of the departments of Environment and ICMBio identifying which parks have approved and available management plans. From the location of these public documents, we looked for in each information on indigenous people, quilombolas, traditional people and communities or local residents inside the units. Among the 124 management

\footnotetext{
37 Ilhabela State Park and Descobrimento National Park
} 
plans found, 27 cases were identified overlap. So at first, the conclusion was the inconsistency of official information given by ICMBio in January 2018. Therefore, in accordance with the official organ there is no overlap of UCPI and traditional people and communities, then why in management plans of Brazilian parks this question becomes evident?

Graphic 1 - State and federal parks overlapped on traditional lands and territories

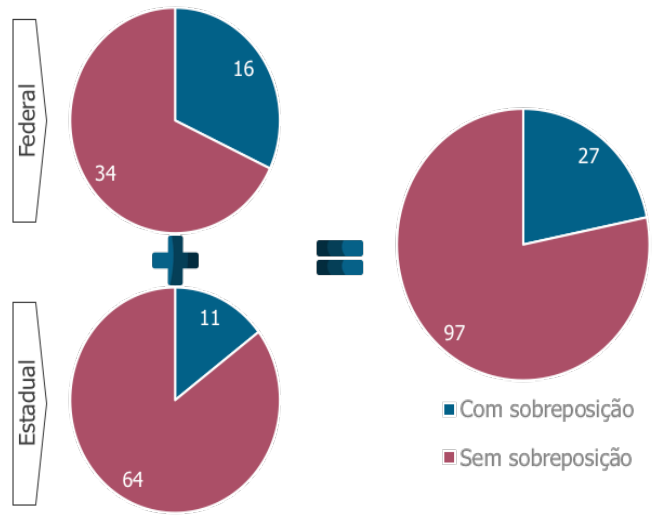

Author's source LIMA, Nathalia. (2018)

From the 27 Brazilian parks that have indigenous and traditional people residing, we tried to distinguish those that are overlapping: 1) the indigenous lands, 2) the quilombo land and 3) traditional territories. As we can see, the overlapping cases occur more frequently in indigenous lands and the territories occupied by traditional communities, and to a lesser extent, in the quilombolas land. Moreover, it is important to explain that if we add the number of overlapping parks to indigenous lands, Quilombolas and the territories occupied by traditional communities, that number is greater than the amount of overlapping cases. This is due to the fact that the same park can be overlapped at the same time, to more than one category of traditional lands and territories, indigenous, quilombolas and other communities.
Graphic 2 - Federal and State Parks overlapped on indigenous lands, quilombolas and traditional territories

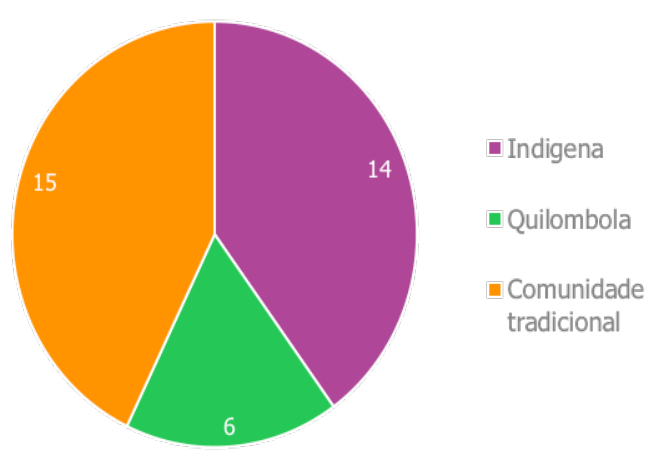

Author's source LIMA, Nathalia. (2018)

\subsubsection{Parks management plans and innovative legal solutions for nature and culture}

Once identified the cases of overlap, the second stage was then verify that the management plans of the parks (state and federal) overlapped on indigenous lands, quilombolas or traditional territories have adopted solutions in order to reconcile the permanence of people and communities with the objective of creation of units and what were the instruments used by most plans.

Most management plans recognized the traditional lands and territories zoning. This fact does not change when we look at the management plans of the state parks in isolation from the feds.

Graphic 3 - Land and territories (indigenous, quilombola and traditional communities) recognized by the zoning of federal and state parks

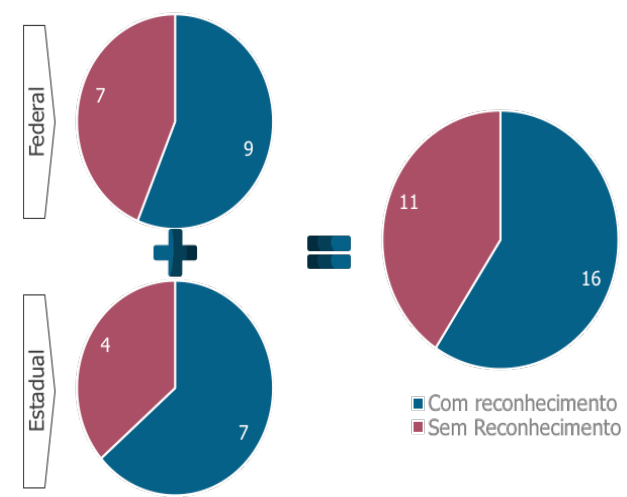

Author's source LIMA, Nathalia. (2018) 
When we analyzed separately each category: indigenous, quilombola and traditional communities, we realized that, regardless of the category of people and communities, most management plans of both the federal and state parks showed some action to solve the normative conflict generated by overlapping.

Graphic 4 - Management plans of federal and state parks that presented solution for cases of overlapping land and indigenous territories, quilombolas and traditional communities
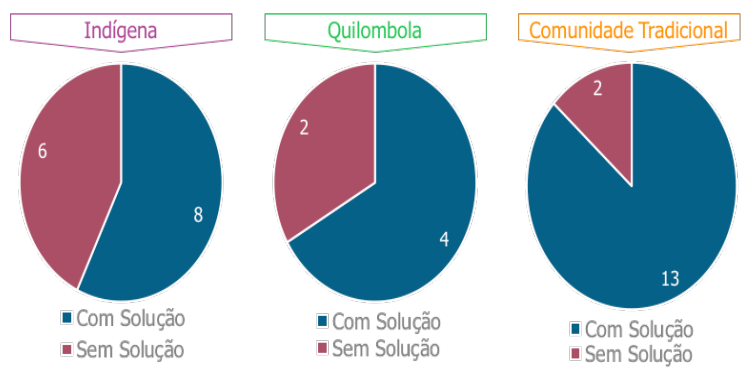

Author's source LIMA, Nathalia. (2018)

Analyzing in detail what was the type of solution presented by management plans in cases of overlapping federal and state parks to indigenous lands; it became clear that the most used instruments were resettlement and zoning. Assessing federal plans separately from the state, we realized that, at the federal level, the data do not change significantly, but the plans of state parks, the only instrument used was the zoning.

Graphic 5 - Instruments used in the management plans of the federal and state parks to resolve the overlapping land and indigenous territories

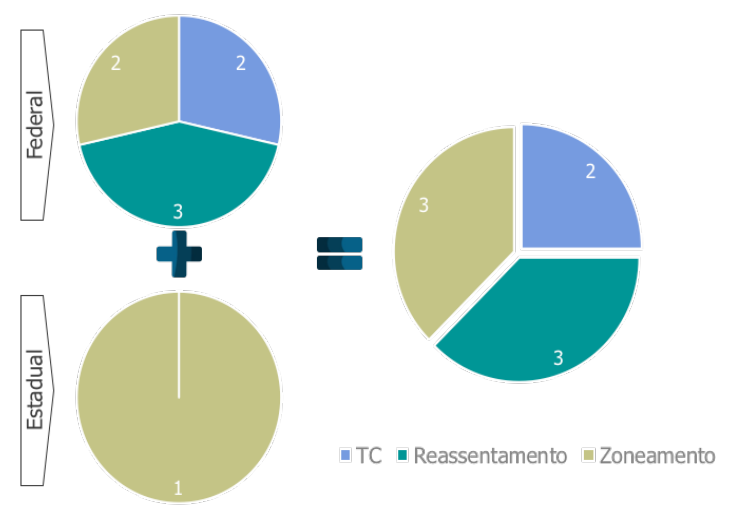

Author's source LIMA, Nathalia. (2018)

With regard to the quilombolas communities, when we analyze in detail the solutions presented by the management plans of the federal and state parks overlapped on their land, we identify arrangement solutions, which is, instruments used in combination. In addition, we observed that, in most cases, the zoning is the instrument that makes up these arrangements. This fact does not change when we separately look at federal and state spheres.

The chart below provides more than one color for each category of analysis, since in this case the management plans do not present as a solution the use of a single instrument. In fact, they used more than one tool to formulate combined solutions (what we call arrangements). For example, at the federal level, one of the parks presented in the management plan a solution made by preparing a term sheet and a proposal for re-categorization of the area occupied by the community. Yet another park in the same sphere, used three different instruments to formulate their solution: zoning, the commitment agreement and resettlement. Thus, a color used to represent each instrument used in the composition of the solutions proposed by the management plans, in order to analyze those that prevail in each of the spheres (state and federal) and considering the whole. At times, there was the use of more than one instrument, because some of the parks allocate traditional communities in the Temporary Occupation Zone and enter into a commitment agreement to regulate the use and occupation of land, but do not fail to provide that community with a day will be resettled.

Graphic 6 - Instruments used in the management plans of the federal and state parks to resolve overlapping in Quilombola lands

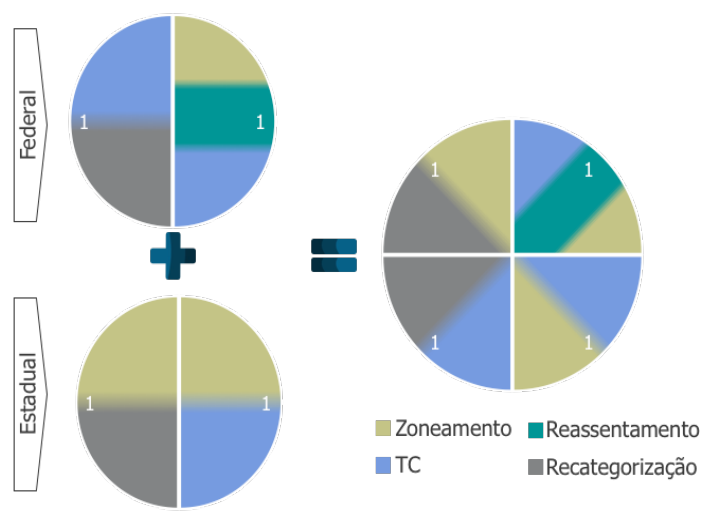

Author's source LIMA, Nathalia. (2018)

As to the other categories of traditional communities to evaluate the solutions presented by the management plans of the federal and state parks overlapped on their territory, we realized that the instrument that appears most frequently is resettlement. However, if we add the other solutions that have been identified, such 
as re-categorization, term sheet and zoning, it is evident that the number of management plans that presented solutions in order to reconcile the permanence of traditional populations residing with the unit's creation goals it is greater than the number of plans that indicate the resettlement as a solution.

Here also the instruments appear in combination. Therefore, we use more than one color in the same category analysis. Among them, the zoning is what else is present in these arrangements. Moreover, when we separate the federal level of the state, we observed that only the management plans of the state parks had zoning as a compliance tool.

Some parks at the state level had very diverse arrangement solutions, coming to use the four instruments (zoning, re-categorization, commitment and resettlement term) in the same management plan to address the overlap of the park to the territory occupied by the traditional community. As it happened to quilombolas communities, some management plans inserted this traditional community in the Temporary Occupation Zone, having signed a term sheet to regulate the use and occupation of land, but leaving open whether to re-categorize the area or resettle the community, providing both possibilities at the same management plan. We believe that this occurs because the choice will depend on the degree of preservation of evident traditionalism of each community, which over time, can be proved by anthropological report.

The future possibility for choosing whether the community will be resettled or if the area corresponding to their territory will be re-categorized can occur in times of review of management plans, as these documents must be updated to the extent that regulate a space that is constantly changing. The ICMBio already conducted a review of 35 management plans at the federal level. ${ }^{38}$

\footnotetext{
38 For more information on the preparation and review of management plans for federal conservation units, see the dynamic panel of ICMBio. Available in: http://qvicmbio.gov.br/QvAJAXZfc/opendoc2.htm?document=painel_corporativo_6476. qvw\&host=Local\&anonymous=true. Accessed on 31 August 2018.
}

Graphic 7 - Instruments used in the management plans of the federal and state parks to resolve overlapping the occupied lands and territories of traditional communities

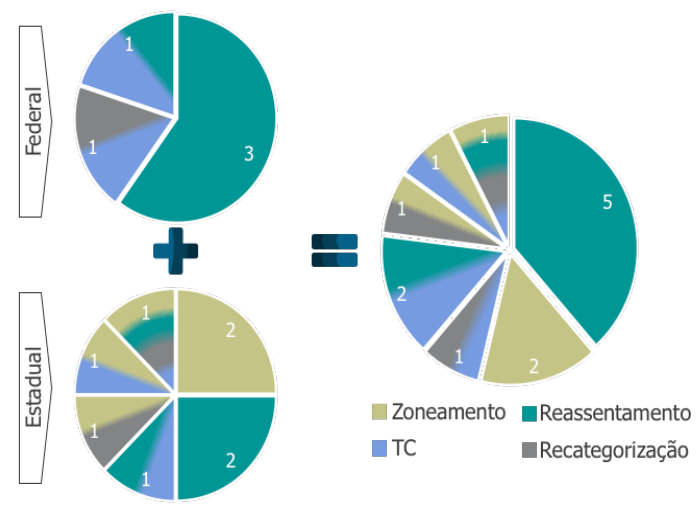

Author's source LIMA, Nathalia. (2018)

Considering the overlapping of the parks to traditional lands and territories (including indigenous, the Quilombolas and traditional communities), when analyzing what instrument prevailed as a solution for the federal and state spheres (analyzed separately), we realized that there was a predominance of the term of commitment and resettlement for the management plans of federal parks. Rather in the plans of state parks, zoning prevailed as compatible instrument between the permanence of people and communities with the unit's goals.

Graphic 8 - instruments identified in the management plans of Brazilian parks
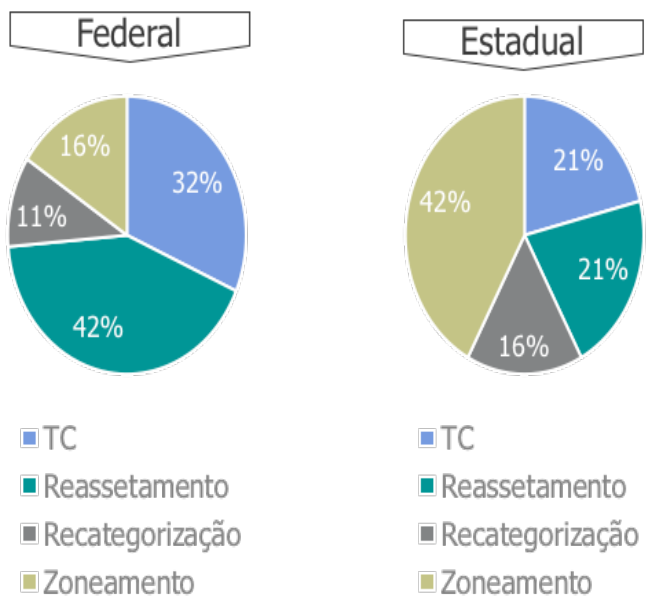

Author's source LIMA, Nathalia. (2018)

In addition to these solutions, we try to understand, in the cases of overlap, with what purpose was created the Historical-Cultural Zone, and whether this zone established the protection for both, material and immaterial cultural heritage. This study was motivated by 
the fact that we found in the case of the State Park of Serra do Mar (PESM), the Anthropological Historical-Cultural Zone and in the Ilha Bela State Park (PEIB), the historical-cultural zone, both as a way to recognize and guarantee the territory historically occupied by traditional communities, such as quilombolas and caiçaras, and emphasize the protection of material and immaterial cultural heritage built by these communities, and ensure their ways of living and sources of livelihood.

Graphic 9 - Historic-Cultural Zone and protection of tangible and intangible assets

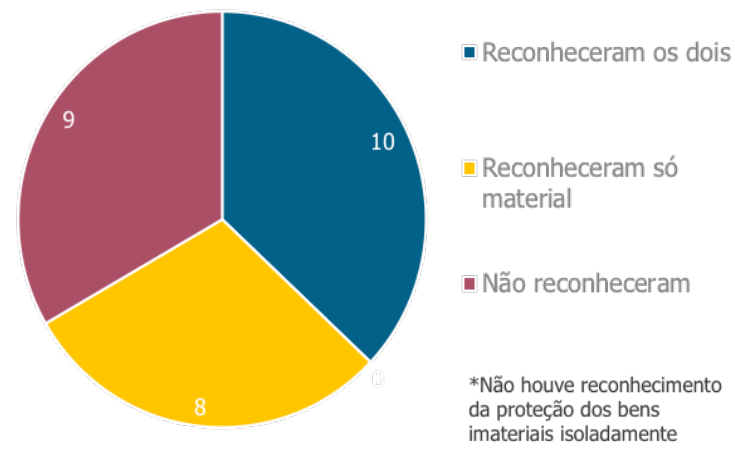

Author's source: LIMA, Nathalia. (2018)

Considering the overlapped parks on traditional lands and territories, eighteen Management Plans (MP) presented the category of Historical-Cultural Zone (ZHC). However, when we check for what purpose this zone was established, we note that ten of them recognized both the protection of material and immaterial goods, but did not recognize the traditional lands and territories, except PESM and PEIB, which mentioned expressly the $\mathrm{ZCH}$ (a) goal to protect the traditional territory beyond the cultural tangible and intangible assets. Regarding PEIB, it is interesting to note that the caiçaras communities signed with the Secretariat of the Union Equity (SPU) the Agreement of Sustainable Use (TAUS). This instrument aims to grant these people the right to ownership of their traditional territory, since the caiçaras did not have a defined legal regime, as it is the case of indigenous and quilombolas.

\section{Final considerations}

Land and natural resources are the main components of the relationship between nature and culture. Given this relationship, when these components are conside- red as one, they come to be called territories. The territorial rights of indigenous people, quilombolas and other traditional communities are critical to the social, economic and cultural reproduction of these groups. Among the social and environmental rights, the right to traditional lands is essential when thinking about strategies for conservation of biodiversity and cultural diversity, because it is a guarantee of land and natural resources that will enable the development of traditional knowledge associated with the sustainable use of these resources.

However, there are situations where biodiversity conservation goes against the protection of cultural diversity and becomes a threat to traditional territories. The Convention on Biological Diversity (CBD) established that each Party shall establish a system of protected areas for conservation of biological diversity. In Brazil, the National System of Conservation Units (Federal Law 9.985/00), besides regulating the creation of specially protected territorial spaces (CF / 88, 225-III article), aims to implement that determination of the CBD as it establishes a regime of creation and management of protected areas. ${ }^{39}$ It happens that this system provides for the possibility to create two management categories of these areas, one a full protection and the other a sustainable use, being that the first does not allow the direct use of natural resources and provides that the traditional resident populations and their limits must be relocated. However, until it is possible to carry out resettlement, actions can be established in order to reconcile the presence of populations with the unit's goals. $^{40}$

On the analysis that we did, one of the tools most used by the management plans of the state parks in the event of any overlap with the lands and territories of indigenous people, quilombola and traditional communities is zoning; in the case of federal parks, the instruments were the commitment agreement and resettlement. The zoning was used in isolation and in conjunction with other instruments, in the formation of combined solutions, such as zoning and re-categorization, zoning and terms of commitment, zoning and shared management tool, zoning and traditional use plan, among others.

39 DUDLEY, N. (ed.) Guidelines for Applying Protected Area Management Categories. Gland, Switzerland: IUCN, 2008.

40 IUCN. From Strategy to Action: the IUCN response to the Report of the World Commission on Environment and Development. Gland: IUCN, 1989. Disponível em: https://portals.iucn. org/library/node/6060. 
Regarding the difference between the legal frameworks that guarantee the right of indigenous and quilombola lands, and the absence of a defined system to other traditional communities, the quantitative analysis has not made clear that there is some influence, because in all categories of people and communities for management plans were presented solutions - including, with respect to traditional communities, those were the cases for which they were presented more solutions. But when we perform a qualitative analysis, we realize that in some cases, different solutions were adopted to the same park overlapped on two traditional territories, an indigenous and other quilombola.

In relation to the existence of an alignment between the legal innovative solutions promoted at the federal level and those that have been developed at the state level, we realize that some instruments appear more frequently in the management plans of the state departments of Environment, such as zoning, while the resettlement and the terms of engagement are mostly used by management plans of the Chico Mendes Institute for Biodiversity Conservation (ICMBio). This fact occurs mainly in the case of overlapping of the parks to the territories occupied by traditional communities, which are precisely those that still lack a legal regime established to ensure the right to their traditional territories. If these solutions proposed for the overlapping of territories can bring together the protection of biological diversity and culture values reconciling culture and nature, they can see as innovative legal solutions to implement CDB.

\section{References}

AMEND, S. Espacios sin habitantes?: Parques nacionales en América del Sur. Barcelona, IUCN: Ed. Nueva Sociedad, 1992.

BORRINI-FEYERABEND, G. et al. Governance of Protected Areas: From understanding to action. Best Practice Protected Area Guidelines Series No. 20. Gland, Switzerland: IUCN, 2013.

CAPUCCI, Maria Rezende. Aspectos fundiários das comunidades caiçaras. In: STANICH NETO, Paulo et al. (org.). Direito das comunidades tradicionais caiçaras. São Paulo: Café Com Lei, 2016.
DIEGUES, Antonio Carlos. "Sustainable Development and People's Participation in Wetland Ecosystem Conservation in Brazil: Two Comparative Studies". In: GHAI, D.; VIVIAM, J. (ed.). Grassroots Environmental Action. New York and London: Routledge, 1992.

DIEGUES, Antonio Carlos. O mito moderno da natureza intocada. São Paulo: HUCITEC, 1996.

DUDLEY, N. (ed.) Guidelines for Applying Protected Area Management Categories. Gland, Switzerland: IUCN, 2008.

GRABNER, Maria Luiza. Os caiçaras e as unidades de conservação de proteção integral: convergência entre os direitos fundamentais das comunidades tradicionais e a conservação ambiental. In: STANICH NETO, Paulo et al. (org.). Direito das comunidades tradicionais caiçaras. São Paulo: Café Com Lei, 2016.

IUCN. From Strategy to Action: the IUCN response to the Report of the World Commission on Environment and Development. Gland: IUCN, 1989. Disponível em: https://portals.iucn.org/library/node/6060.

LEUZINGER, Márcia Dieguez et al. Espaços territoriais especialmente protegidos: extensão, limites e oportunidades. Brasilia: Uniceub, 2015.

LEUZINGER, Márcia Dieguez; LINGARD, K. The Land Rights of Indigenous and Traditional Peoples in Brazil and Australia. Revista de Direito Internacional, Brasilia, v.13, p. 60-80, 2016.

LEUZINGER, Márcia Dieguez. Natureza e cultura: unidades de conservação de proteção integral e populações tradicionais residentes. Curitiba: Letra da Lei, 2009.

LIMA, Nathalia Fernandes. Gestão de áreas protegidas: instrumentos para implementação dos direitos socioambientais nos parques brasileiros marinhos costeiros. 2018. 106 f. Dissertação (Mestrado) - Curso de Direito, Programa de Direito Político e Econômico, Universidade Presbiteriana Mackenzie, São Paulo, 2018. Cap. 2.

LITTLE, Paul E. Territórios Sociais e Povos Tradicionais no Brasil: por uma antropologia da territorialidade. Série Antropologia. Brasília: Universidade de Brasília, 2002.

MARÉS, Carlos Frederico. Bens culturais e proteção jurídica. Porto Alegre: Unidade Editorial da Prefeitura, 2011. 
MARTIN, Paul; LEUZINGER, Márcia Dieguez; SILVA, Solange Teles. "Improving the Effectiveness of Legal Arrangements to Protect Biodiversity: Australia and Brazill". Revista de Direito Internacional, Brasília, v. 13, p. 25-36, 2016.

MARTIN, Paul; BOER, Ben; SLOBODIAN, Lydia (ed.). Framework for Assessing and Improving Law for Sustainability. Gland, Switzerland: IUCN, 2016.

REGINATO, Andréa Depieri de. Uma introdução à pesquisa documental. In: MACHADO, Maíra Rocha (org.). Pesquisar empiricamente o direito. São Paulo: Rede de Estudos Empíricos em Direito, 2017.
SANTILLI, Juliana. Socioambientalismo e novos direitos. Realização: Instituto Internacional de Educação do Brasil (IEB) e Instituto Socioambiental (ISA). São Paulo: Peirópolis, 2005.

WORBOYS, G. L. et al. (ed.) Protected Area Governance and Management. Camberra, Austrália: ANU Press, 2015. 
Para publicar na Revista de Direito Internacional, acesse o endereço eletrônico www.rdi.uniceub.br ou www.brazilianjournal.org.

Observe as normas de publicação, para facilitar e agilizar o trabalho de edição. 